\title{
Perception towards the Preparedness for Disaster Management among Nurses in Community Clinics
}

Fatimah Sham, Lailatul Hazzliza Musa, Nor Marini Mohamed, Norjah Othman

\author{
Faculty of Health Sciences, Universiti Teknologi MARA, Malaysia \\ 42300 Puncak Alam, Selangor, Malaysia \\ Email:azfa4518@yahoo.com
}

Received: 18 September 2018

Accepted: 30 October 2018

\section{ABSTRACT}

Disasters are defined as extraordinary events which occur abruptly, bringing great damage or harm, loss, and destruction to people and the environment. Nurses may have a more conflict and difficulties in disaster decision making where the victim condition need to be treated in disaster place. Nurses play a key role in hospital as a leaders and managers in the disaster operation and command center but limited data shows that the nurses experience in disaster management. The aim of this study is to evaluate the perception of knowledge and skills on the preparedness in disaster management among nurses in community clinics. A descriptive cross-sectional study was conducted in 27 government clinics in one of the states in Malaysia with a convenient sampling, 260 participants are selected. The questionnaire consisted of three sections; socio-demographic characteristics, the perception of knowledge and skill towards preparedness for disaster management rated on a Likert scale. In the effort to collect the intended data, a self-report questionnaire adapted and modified from Disaster Preparedness Evaluation Tool (DPET) was implemented (Alrazeeni, 2015). This study revealed that Nurses in these community clinics were moderate in terms of the perception of knowledge (Mean $=3.65$, $S D=0.61)$ and the perceived skills (Mean=3.68, $S D=0.56)$ on the preparedness in Disaster Management. Nevertheless, they were interested in disaster preparedness management training $(n=227,87.3 \%)$ and were confident as first responders of disaster (Mean $=3.88, S D=0.61$ ). However, 
they were not much involved in disaster preparedness plan (Mean $=3.23$, $S D=0.90$ ) and claimed that there was a lack of leadership figure in disaster situation (Mean= 3.06, SD=0.92). In conclusion, nurses in community clinics need to gain knowledge and skills by involving themselves in disaster planning and drills as the preparation for disaster management for them to be the first responders in helping and managing people in this situation.

Keywords: perception, disaster management, nurses, community clinic, knowledge

\section{INTRODUCTION}

A disaster is defined as a serious disruption of community or society which causes human, material, economic or environmental losses or harm. A disaster would usually exceed the ability of the affected community or society as a whole to cope using its own resources (Alrazeeni, 2015; Diab \& Mabrouk, 2015).

Meanwhile, disaster preparedness is referred to the state of readiness of an organisation to respond successfully to disaster situations while also reducing the negative aftermaths for the health and safety of individuals and the integrity and function of the physical structure and system (Conlon \& Wiechula, 2011).

In the disaster operations and command centre, public health nurses play important roles not only as the front-line responders to serve for the public health service but also as leaders and managers (Magnaye, M, Ann, Gilbert, \& Heather, 2011). They also play important roles in promoting the development of a caring and healthy community in which this field remains healthy and stable through land use rules and building codes.

All members of healthcare teams should be trained to work together during any disaster. Since the healthcare team is among the first to deal with these conditions, they should be prepared (Veenema, 2013). Nurses' roles are important in response of accidents, disasters and bioterrorism. In order 
to meet these necessities, it is undeniable that they must be properly trained to be prepared with knowledge and (Pourvakhshoori, Norouzi, Ahmadi, Hosseini, \& Khankeh, 2016).

\section{SIGNIFICANCE OF THE STUDY}

After a few series of disasters happening such as tsunamis, landslides and a few cases of building collapses, the Malaysian government has been triggered to improve the disaster management planning (N. Ahayalimudin, 2016).

The Directive No.20, the main policy for disaster management in Malaysia, guides agencies across the nation in managing disasters and its aftermaths. This includes the preparedness of health care providers in assisting the community as the risks of emerging diseases and facing the dynamic of health care system would rise tremendously during times of disasters (R. Roosli, 2012). Since any disaster can strike without warning, it is important that the health care team needs to be familiar with their own disaster and management policies (Garnett \& Moore, 2010).

The preparedness is and the higher determination to handle the situation should be inculcated. Knowledge and skills in disaster management should be developed to implement the education and training relevant to disaster management. This is to ensure the preparedness as well as assistance for the affected communities are delivered during a disaster.

There are several studies focusing on emergency nurses and medical personnel working in hospital but very limited study was done amongst the community health nurses when actually they are the first individuals who would be referred to whenever any disaster involving casualties happens.

The aim of this study is to evaluate the perception of knowledge and skills on the preparedness in disaster management among nurses in community clinics. 


\section{METHOD}

\section{Research Design}

A descriptive cross-sectional study was selected for this study. This study was conducted in 27 government community health clinics in Kuala Lumpur which provide Primary Health Care. The samples were nurses from community health clinics with minimum of one year experience. The total population of nurses in this district was 801 . Convenient sampling was chosen to select 260 nurses in the respective community clinics to participate in the study with the Confidence Interval of 5\% and the Confidence Level of $95 \%$. The exclusion subjects were nurses who disagreed to participate in the study and nurses who were on leave or Maternity Leave.

A set of self-administered questionnaire adapted from Disaster Preparedness Evaluation Tool (DPET) by Alrazeeni was implemented in the study (2015). This questionnaire was designed to evaluate the perception of knowledge and skills on the preparedness in disaster management among nurses in community clinics.

There were three sections in the questionnaire. The first section was on the participants' demographic data. This section included their age, gender, marital status, ethnic, education level, and working experience. Additional information regarding their involvement in managing disasters and history of training or courses related to disaster management were also asked. The second section was on the perception of knowledge towards the preparedness for disaster management (16 questions). While the third section was regarding the perceived skills on disaster management (20 questions). Both of these sections were rated on a Likert scale ranging from 'strongly disagree' to 'strongly agree'.

The questionnaire was prepared bilingually; Malay and English. The translation process was validated by accredited translators from Malaysian Institute of Translation and Books. With the final versions of the questionnaire, a pilot study was carried out to test the feasibility of the study and the time needed to answer the questionnaire. The participants took 15-20 minutes on average to complete the questionnaire. 
In order to obtain the data, the researcher approached the nursing leaders and managers in this district. Brief explaination was given and an appointment was arranged for data collection in each of the community clinic involved. On the day of data collection, respondents were gathered in a meeting room and were briefly explained regarding the study. Information sheets containing a statement assuring participant's anonymity and confidentiality was also distributed before gaining the written consent. Respondents were given 15-20 minutes to answer the questionnaire and they were requested to complete the questionnaire on the spot, with the availability of the researcher at the site for assistance.

This study was registered under National Medical Research Register for Medical Research (NMRR-16-2626-33093) and approved by the UiTM Research Ethics Committee (600-RMI (5/1/6), Community Research Centre (CRC) Hospital Kuala Lumpur (HKL/CRC/SL/06) and Medical Research Ethics Committee (MREC); (5) KKM/NIHSEC/P17-560.

\section{Data Analysis}

The data were analysed using SPSS (IBM Corp. Released 2011. IBM SPSS for Windows, Version 20.0 Armonk, NY). The data were cleaned and a reliability test was conducted to determine the consistency of a research study. The Cronbach's alpha value was 0.94 , showing an excellent consistency of the data.

\section{RESULTS}

The characteristics of the respondents in this sample were presented in Table 1. The mean age of the respondents was 34.15 years of age $(\mathrm{SD}=7.13)$. Most of the respondents was at the age of 31 to 40 years old $(n=126 ; 53 \%)$. The proportion of female respondents was larger compared to the male respondents at $64.6 \%(n=168)$ and $35.4 \%(n=92)$ respectively. Most of them were married $(59.6 \%, n=155)$. Majority of these nurses were Malay $(93.1 \%, n=242)$. Their working experience were about 10.09 years $(\mathrm{SD}=6.67)$. About $51.5 \%((n=134)$ of these nurses were Registered Nurses 
SCIENTIFIC RESEARCH JOURNAL

$(\mathrm{RN})$. Majority of them had no experience in disaster management (84.6\%, $n=220)$ while $58.8 \%(n=153)$ claimed they had attended training or courses related to disaster management.

Table 1: Demographical Characteristics of the Respondents $(n=260)$

\begin{tabular}{|c|c|c|}
\hline Variables & Frequency $(n)$ & Percentage (\%) \\
\hline Age & \multicolumn{2}{|c|}{ Mean: 34.15 years old (SD:7.13) } \\
\hline$<25$-year-old & 25 & 10 \\
\hline 26 to 30 -year-old & 60 & 23 \\
\hline 31 to 35 -year-old & 80 & 31 \\
\hline 36 to 40 -year-old & 57 & 22 \\
\hline >40-year-old & 38 & 15 \\
\hline \multicolumn{3}{|l|}{ Gender } \\
\hline Female & 168 & 64.6 \\
\hline Male & 92 & 35.4 \\
\hline \multicolumn{3}{|l|}{ Marital Status } \\
\hline Single & 105 & 40.4 \\
\hline Married & 155 & 59.6 \\
\hline \multicolumn{3}{|l|}{ Ethnic } \\
\hline Malay & 242 & 93.1 \\
\hline Indian & 7 & 2.7 \\
\hline Others & 11 & 4.2 \\
\hline \multicolumn{3}{|l|}{ Level of Education } \\
\hline Diploma & 149 & 57.3 \\
\hline Degree & 3 & 1.2 \\
\hline Master & 1 & 0.4 \\
\hline Others & 107 & 41.2 \\
\hline Work Experience & \multicolumn{2}{|c|}{ Mean: 10.09 years (SD:6.67) } \\
\hline$<4$-years & 58 & 22 \\
\hline 5 to 10 -years & 89 & 34 \\
\hline 11 to 20 -years & 92 & 35 \\
\hline >20-years & 21 & 8 \\
\hline \multicolumn{3}{|l|}{ Grade } \\
\hline U19 & 97 & 37.3 \\
\hline U24 & 13 & 5.0 \\
\hline
\end{tabular}




\begin{tabular}{lcc} 
U26 & 6 & 2.3 \\
U29 & 134 & 51.5 \\
U32 & 10 & 3.8 \\
\hline Involve in Disaster Management & & \\
Yes & 40 & 15.4 \\
No & 220 & 84.6 \\
\hline Attended Courses related to Disaster Management & \\
Yes & 153 & 58.8 \\
No & 107 & 41.2
\end{tabular}

\section{The Perception of Knowledge on the Preparedness in Disaster Management}

The perception of knowledge towards the preparedness for disaster management among nurses in these community clinics were presented in Table 2. This study revealed that the respondents had perceived their knowledge to be moderate when it comes to the preparedness in Disaster Management (Mean=3.65, SD=0.61). More than half of the respondents agreed they had knowledge on the preparedness in Disaster Management $(n=171,65.8 \%)$. They claimed they were interested in disaster preparedness management training $(\mathrm{Mean}=4.04, \mathrm{SD}=0.71)$. However, they had less participation in disaster preparedness plans in their community $(\mathrm{Mean}=3.23, \mathrm{SD}=0.90)$.

Table 2: The Perception of Knowledge towards the Preparedness for Disaster Management

\begin{tabular}{|c|l|c|c|}
\hline NO & QUESTION & MEAN & SD \\
\hline 1 & $\begin{array}{l}\text { I participate in disaster drills or exercises at my } \\
\text { workplace on a regular basis. }\end{array}$ & 3.43 & 0.87 \\
\hline 2 & $\begin{array}{l}\text { I participate in disaster preparedness plans in my } \\
\text { community. }\end{array}$ & 3.23 & 0.90 \\
\hline 3 & $\begin{array}{l}\text { I know who to contact when facing disaster in my } \\
\text { community. }\end{array}$ & 3.74 & 0.70 \\
\hline
\end{tabular}




\begin{tabular}{|c|l|c|c|}
\hline 4 & $\begin{array}{l}\text { I participate in educational activities on a regular } \\
\text { basis: continuing education classes (CME), seminars, } \\
\text { or conferences dealing with disaster preparedness } \\
\text { management. }\end{array}$ & 3.47 & 0.87 \\
\hline 5 & I read journals / articles related to disaster preparedness. & 3.66 & 0.73 \\
\hline 6 & $\begin{array}{l}\text { I am aware of disaster preparedness management } \\
\text { training offered at my workplace or in the community. }\end{array}$ & 3.44 & 0.78 \\
\hline 7 & $\begin{array}{l}\text { I am interested in disaster preparedness management } \\
\text { training. }\end{array}$ & 4.04 & 0.71 \\
\hline 8 & $\begin{array}{l}\text { I find the research literature on disaster preparedness } \\
\text { management easily accessible. }\end{array}$ & 3.42 & 0.80 \\
\hline 9 & $\begin{array}{l}\text { I find the research literatures on disaster preparedness } \\
\text { understandable. }\end{array}$ & 3.60 & 0.71 \\
\hline 10 & $\begin{array}{l}\text { Finding relevant information about disaster preparedness } \\
\text { related to my community needs is an obstacle to my } \\
\text { level of preparedness. }\end{array}$ & 3.52 & 0.65 \\
\hline 11 & $\begin{array}{l}\text { I know where to find relevant information related to } \\
\text { disaster preparedness management. }\end{array}$ & 3.51 & 0.67 \\
\hline 12 & $\begin{array}{l}\text { I know the list of contact person in case I'm facing } \\
\text { disaster situation. }\end{array}$ & 3.55 & 0.70 \\
\hline 13 & $\begin{array}{l}\text { In case l'm facing a disaster situation, I think there is } \\
\text { sufficient support from the upper level. }\end{array}$ & 3.86 & 0.67 \\
\hline 14 & I know the potential disaster risks in my community. & 3.76 & 0.67 \\
\hline 15 & I know my limits when facing disaster. & 3.65 & 0.69 \\
\hline 16 & $\begin{array}{l}\text { I am confident in recognizing differences in assessments } \\
\text { and indicating potential exposure to biological or } \\
\text { chemical agents. }\end{array}$ & 3.42 & 0.76 \\
\hline & TOTAL & $\mathbf{0 . 6 5}$ \\
\hline
\end{tabular}

\section{The perceived skills towards Disaster Management}

The perceived skills towards Disaster Management among nurses in these community clinics were presented in Table 3 . This study revealed that the respondents had moderate perceived skills on the preparedness in Disaster Management (Mean= 3.93, $\mathrm{SD}=0.56$ ). More than half of the respondents agreed they had skills on the preparedness in Disaster Management ( $n=197,75.7 \%)$. They claimed they were confident with their abilities as health care responders in any disaster (Mean=3.88, $\mathrm{SD}=0.61$ ). However, they noted that there was lacking a leadership figure in disaster situation $($ Mean $=3.06, \mathrm{SD}=0.92)$. 
Table 3: The perceived skills towards Disaster Management

\begin{tabular}{|c|c|c|c|}
\hline NO & QUESTION & MEAN & SD \\
\hline 1 & $\begin{array}{l}\text { I consider myself prepared for the management of } \\
\text { disasters. }\end{array}$ & 3.70 & $(0.69)$ \\
\hline 2 & $\begin{array}{l}\text { I participate/have participated in creating new guidelines, } \\
\text { emergency plans, or lobbying for improvements on the } \\
\text { local or national level. }\end{array}$ & 3.32 & $(0.77)$ \\
\hline 3 & $\begin{array}{l}\text { I would be considered a key leadership figure in my } \\
\text { community in a disaster situation }\end{array}$ & 3.06 & $(0.92)$ \\
\hline 4 & $\begin{array}{l}\text { In case of a bioterrorism/biological or chemical attack, I } \\
\text { know how to use personal protective equipment. }\end{array}$ & 3.89 & $(0.69)$ \\
\hline 5 & $\begin{array}{l}\text { In case of a bioterrorism/biological or chemical attack, I } \\
\text { know how to execute decontamination procedures. }\end{array}$ & 3.48 & $(0.67)$ \\
\hline 6 & $\begin{array}{l}\text { In case of bioterrorism/biological or chemical attacks, } \\
\text { I know how to perform isolation procedures so that I } \\
\text { minimise the risks of community exposure. }\end{array}$ & 3.68 & $(0.70)$ \\
\hline 7 & $\begin{array}{l}\text { I am familiar with the local emergency response system } \\
\text { for disasters. }\end{array}$ & 3.80 & $(0.64)$ \\
\hline 8 & $\begin{array}{l}\text { I am familiar with the accepted triage principles used in } \\
\text { disasters. }\end{array}$ & 3.78 & $(0.65)$ \\
\hline 9 & $\begin{array}{l}\text { I have personal/family emergency plans in place for } \\
\text { disasters. }\end{array}$ & 3.74 & $(0.65)$ \\
\hline 10 & $\begin{array}{l}\text { I have an agreement with loved ones and family members } \\
\text { on how to execute our personal/family emergency plans. }\end{array}$ & 3.73 & $(0.70)$ \\
\hline 11 & $\begin{array}{l}\text { I can describe my role in the response phase of a disaster } \\
\text { (in the context of my workplace, the general public, media, } \\
\text { and personal contacts). }\end{array}$ & 3.79 & $(0.61)$ \\
\hline 12 & $\begin{array}{l}\text { I am familiar with the main Groups (A, B, C) of biological } \\
\text { weapons (Anthrax, Plague, Botulism, Smallpox, etc.), } \\
\text { signs and symptoms, and effective treatments. }\end{array}$ & 3.26 & $(0.71)$ \\
\hline 13 & $\begin{array}{l}\text { As a nurse, I am confident in my abilities as a health care } \\
\text { provider and first responder in disaster. }\end{array}$ & 3.93 & $(0.58)$ \\
\hline 14 & $\begin{array}{l}\text { As a nurse, I am confident to be a manager or coordinator } \\
\text { of a shelter. }\end{array}$ & 3.70 & $(0.69)$ \\
\hline 15 & $\begin{array}{l}\text { As a nurse, I am confident in my abilities to be a member } \\
\text { of a decontamination team. }\end{array}$ & 3.78 & $(0.62)$ \\
\hline 16 & $\begin{array}{l}\text { In case I encounter a disaster, I know how to do history } \\
\text { taking and physical assessment. }\end{array}$ & 3.88 & $(0.61)$ \\
\hline 17 & $\begin{array}{l}\text { I am confident that I can manage patients independently } \\
\text { without physician supervision in disaster. }\end{array}$ & 3.48 & $(0.85)$ \\
\hline
\end{tabular}




\begin{tabular}{|c|l|c|c|}
\hline 18 & $\begin{array}{l}\text { I am familiar with the organisational logistics and roles } \\
\text { among local and national agencies in disaster response. }\end{array}$ & 3.12 & $(0.81)$ \\
\hline 19 & $\begin{array}{l}\text { I am confident in implementing emergency plans and } \\
\text { evacuation procedures. }\end{array}$ & 3.47 & $(0.68)$ \\
\hline 20 & $\begin{array}{l}\text { I feel confident in providing health education in case of } \\
\text { acute stress among the victim. }\end{array}$ & 3.65 & $(0.64)$ \\
\hline & TOTAL SCORE & 3.68 & $\mathbf{( 0 . 5 6 )}$ \\
\hline
\end{tabular}

\section{DISCUSSION}

This study demonstrated that nurses in these community clinics had a moderate level of perceived knowledge and skills on the preparedness in Disaster Management. These results were similar with a study done by Al Thobaity et al. (2015) which concluded that nurses in Saudi Arabia had moderate knowledge concerning the disaster preparedness. They also claimed they were interested in disaster preparedness management training and confident with their abilities as health care responders in a disaster. However, they were reported to have participated less in disaster preparedness plans in their community and lacking a leadership figure in disaster situation.

This shows that the need for a formal education and on-going disaster management education is significant to improve nurses' abilities, confidence and competency to coordinate effectively.

Fung et al. (2008) found that nurses in Hong Kong felt that disaster drills were important and useful tools in building disaster competencies. Hammad et al. (2011) on the other hand concluded that regular disaster drills allow nurses to understand their roles in real disasters. Thus, regular disaster drills are useful in training nurses to respond confidently and competently when disasters strike.

Nurses in many countries are not permitted to be involved in developing plans and guidelines for several reasons, including gender issues. From the findings, it is highly recommended that nurses start to get involved in the planning for disasters and understand disaster preparedness better, wherever culturally appropriate. 


\section{CONCLUSION}

This current study revealed that the community health nurses had a moderate level of perceived knowledge on the preparedness in Disaster Management. Despite the moderate level, the respondents were interested in disaster preparedness management training. But they were not confident in participating in the drafting of any emergency plan and planning of emergency for disaster situations in their community.

They also had a moderate level of perceived skills on their preparedness in Disaster Management which means the respondents in this study were lacking skills. Almost every respondent did not consider his or himself as a key leadership figure in their community when facing a disaster situation. Thus, it can be concluded that the respondents in this study were good in perception of skills but they need to improve their skills as they are still not confident in handling disaster situations.

\section{FUNDING}

This research did not receive any specific grant from any funding agencies of the public, commercial, or non-profit sectors.

\section{ACKNOWLEDGMENT}

We are grateful to respected personnel of Universiti Teknologi MARA (UiTM), Community Research Centre (CRC) HKL, Health Department, Wilayah Persekutuan Kuala Lumpur (JKWPKL) and all the nurses, who participate in this study. We would also like to thank the Director General of the Ministry of Health Malaysia for his permission to publish this article. 


\section{REFERENCES}

[1] N. Ahayalimudin, and N.N.S. Osman, 2016. Disaster management: Emergency nursing and medical personnel's knowledge, attitude and practices of the East Coast hospitals of Malaysia, Australasian Emergency Nursing Journal, Vol. 19(4), pp. 203-209. Doi: 10.1016/j. aenj.2016.08.001.

[2] F.A. Abdelghany Ibrahim, 2014. Nurses knowledge, attitudes, practices and familiarity regarding disaster and emergency preparedness-Saudi Arabia, American Journal of Science, Vol. 3(2), pp. 18-25. Doi: 10.11648/j.ajns.20140302.12.

[3] N. Ahayalimudin, A. Ismail, and I. Saiboon, 2012. Disaster management: a study on knowledge, attitude and practice of emergency nurse and community health nurse. BMC Public Health, 12(Suppl 2), A3. Doi: 10.1186/1471-2458-12-S2-A3.

[4] A. Al Thobaity, V. Plummer, K. Innes, and B. Copnell, 2015. Perceptions of knowledge of disaster management among military and civilian nurses in Saudi Arabia, Australasian Emergency Nursing Journal, Vol. 18(3), pp. 156-164. Doi: 10.1016/j.aenj.2015.03.001.

[5] D. Alrazeeni, 2015. Saudi EMS Students' perception of and attitudes toward their preparedness for disaster management, Journal of Education and Practice, Vol. 6(35), pp. 110-116.

[6] L. Conlon and R. Wiechula, 2011. Preparing nurses for future disasters-The Sichuan experience, Australasian Emergency Nursing Journal, Vol. 14(4), pp. 246-250. Doi: https://doi.org/10.1016/j. aenj.2011.08.001.

[7] G. M. Diab, and S. M. Mabrouk, 2015. The effect of guidance booklet on knowledge and attitudes of nurses regarding disaster preparedness at hospitals, Journal of Nursing Education and Practice, Vol. 5(9), pp. 17-31. 
[8] K. S. Hammad, P. Arbon and K. M. Gebbie, 2011. Emergency nurses and disaster response: An exploration of South Australian emergency nurses' knowledge and perceptions of their roles in disaster response, Australasian Emergency Nursing Journal, Vol. 14(2), pp. 87-94. Doi: https://doi.org/10.1016/j.aenj.2010.10.002..

[9] B. Magnaye, Ma. Steffi Lindsay M. Muñoz, Mary Ann F. Muñoz, Rhogen Gilbert V. Muñoz and Jan Heather M. Muro, 2011. The Role, Preparedness and Management of Nurses during disasters, E-International Scientific Research Journal, Vol. 3(4).

[10] N. Pourvakhshoori, K. Norouzi, F. Ahmadi, M. Hosseini and H. Khankeh, 2016. Nursing in disasters: A review of existing models, International Emergency Nursing, Vol. 31. Doi: 10.1016/j. ienj.2016.06.004.

[11] Roosli, Ruhizal, 2010. Managing disasters in Malaysia: the attitude of officials towards compliance with the MNSC Directive 20. Unpublished $\mathrm{PhD}$ thesis, Northumbria University.

[12] T. Veenema, T., 2013. No Title Disaster Nursing and Emergency Preparedness for Chemical, Biological, and Radiological Terrorism: An International Curriculum for the Twenty-First Century, Prehospital and Disaster Medicine, Vol. 20(S1), pp. 58-58. Doi: 10.1017/ S1049023X00013212.

[13] Jeffrey D. Garnett and Melinda Moore, 2010. Enhancing Disaster Recovery: Lessons from Exemplary International Disaster Management Practices, Journal of Homeland Security and Emergency Management, Vol. 7(1). DOI: 10.2202/1547-7355.171.

[14] Fung OW, \& Loke AY, Lai CK. (2008). Disaster Preparedness among Hong Kong Nurses, Journal of Advanced Nursing, Vol. 62(6), 698-703. 
